\title{
A Review of Problem and Pathological Gambling in North Cyprus
}

\author{
Mehmet ÇAKICI ${ }^{1}$, Ebru ÇAKICI ${ }^{1}$, Meryem KARAAZIZZ ${ }^{2}$, Asra BABAYİĞİT ${ }^{3}$
}

\begin{abstract}
This review article discusses the prevalence and causes of the problem and pathological gambling in North Cyprus. In Northern Cyprus, pathological gambling is spreading very rapidly. The prevalence of gambling cannot be explained by the widespread use of casinos. In some countries, gambling prevalence may stop if adaptation to gambling occurs. There are many factors affecting the prevalence of gambling. Each country has its own sociocultural conditions. In some countries, in some countries, the presence of a minority affects the prevalence of pathological gambling. Particularly high prevalence of pathological gambling can be explained by sociocultural reasons. The regions with extremely high pathological gambling addiction have similar characteristics. As adaptation to gambling has not taken place in these countries, the prevalence of pathological gambling continues to increase. There fore, understanding the causes of pathological gambling in these countries will have a significant benefit in the preparation of prevention programs. Prevention programs are needed in Northern Cyprus due to the rapid growth of pathological gambling. It is necessary to take into account the sociocultural reasons and the culturalization characteristics in the prevention programs to be prepared.
\end{abstract}

Key Words: Gambling, Pathological Gambling, North Cyprus.

\section{Kuzey Kıbrıs’ta Problem ve Patolojik Kumar Üzerine Bir Derleme}

Özet: Bu derleme yazısı Kuzey Kıbrıs'taki problem ve patolojik kumarın yaygınlığını ve nedenlerini tartışmıştır. Kuzey Kıbrıs’ta patolojik kumarın çok hızlı bir şekilde yayıldığı görülmektedir. Kumar yaygınlığı tek başına kumarhanelerin yaygınlaşması ile açıklanamamaktadır. Bazı ülkelerde kumara yönelik adaptasyon gerçekleşmesi halinde kumar yaygınlığının yükselmesi durabilmektedir. Kumar yaygınlığını etkileyen pek çok faktör bulunmaktadır. Her ülkenin kendine özgü sosyokültürel koşulları bulunmaktadır. Bazı ülkelerde göçmen olma bazı ülkelerde ise azınlık olma yapısı patolojik kumar yaygınlığını etkilemektedir. Özellikle aşırı yüksek patolojik kumar yaygınlığı da sosyokültürel nedenlerle açıklanabilmektedir. Aşırı yüksek patolojik kumar bağımlılı̆̆ bulunan bölgelerin birbirlerine benzeyen ortak özellikleri bulunmaktadır. Bu ülkelerde kumara yönelik adaptasyon gerçekleşmediği için patolojik kumar yaygınlığı artmaya devam etmektedir. Dolayısyla bu ülkelerdeki patolojik kumar nedenlerini anlayabilmenin önleme programlarının hazırlanmasında önemli oranda faydası olacaktır. Kuzey Kıbrıs'ta da hızlı büyüyen patolojik kumar yaygınlığı nedeniyle önleme programlarına ihtiyaç bulunmaktadır. Hazırlanacak önleme programlarında sosyokültürel nedenleri ve akültürasyon özelliklerini dikkate almak gerekmektedir.

Anahtar Kelimeler: Kumar, Patolojik Kumar, Kuzey Kıbrıs.

\footnotetext{
${ }^{1}$ Prof. Dr., Near East University, Faculty of Art and Science, Department of Psychology, Nicosia-Cyprus, Mersin 10 Turkey

${ }^{2}$ Assst. Prof. Dr. Meryem Karaaziz, Near East University, Faculty of Arts and Science, Department of Psychology, Nicosia-Cyprus, Mersin 10 Turkey

${ }^{3}$ MSc., Near East University, Faculty of Arts and Science, Department of Psychology, Nicosia-Cyprus, Mersin 10 Turkey

Address of correspondence/ Yazışma adresi: MSc. Asra Babayiğit, Near East University, Faculty of Arts and Science, Department of Psychology, Nicosia-Cyprus, Mersin 10 Turkey, E-mail: asra.babayigit@neu.edu.tr
}

Date of received/ GelişTarihi: 02.08.2019, Date of acceptance/ Kabul Tarihi: 05.08.2019

Citing/ Referans Gösterimi: Çakıcı, M., Çakıcı, E., Karaaziz, M. \& Babayiği, A., (2019). A Review of Problem and Pathological Gambling in North Cyprus. Cyprus Turkish Journal of Psychiatry \& Psychology, 1(2): 123-28 doi:10.35365/ctjpp.19.1.15 


\section{Introduction}

Betting, card playing, and other games of chance have long significant place in Cypriot life. Whilst the state lottery, horse-racing and football betting are the only licensed forms of gambling in the south, a small number of casinos, modelled on the private clubs run by Turkish Cypriots during the 1950s and 60s, was long in operation in the North (Scott, 2013). After the war in Cyprus, North Cyprus has entered into the political and economic sanctions. North Cyprus has gone to the economic solution which has based upon tourism industry (Alipour \& Vughaingmeh, 2010). Till to the 1991, only four small premises has been working in North Cyprus (Scott, 2001) which after 1997 casino gambling has expanded exponentially. Mounting reports of widespread problem gambling and stories linking casinos with organized crime and corrupt politicians, result of the reactions from the public and the media casino gambling was prohibited in Turkey (Duvarc1 \& Varan, 2000). After that time, large part of casinos moved immediately to NC (Scott, 2003) and over the past 15 years the casino sector has grown and internationalised with over 20 casinos opening on the casino resort model adapted from Las Vegas (Scott, 2001). Most of the gamblers come from Turkey and Greek Part of Cyprus, where gambling is illegal (Scott \& Asikoglu, 2001). Besides the casinos, betting offices, state lottery of NC and Turkey, Sport Lotto, Sport Totto, Instant Scratch Cards, Numerical Lotto for the financing of Sport Clup are legal gambling in NC.

Numerous studies reveal the serious adverse psychological, social, and biological consequences of gambling for some people (Lesieur \& Rosenthal, 1991).People experiencing severe adverse reactions to gambling have become known as "compulsive," "addicted," "disordered," "pathological," or more recently "problem" gamblers (Campbell \& Smith, 2003). In gambling literature those terms often used interchangeable. People experiencing difficulties with gambling can be group into two categories: (1) Problem gamblers and, (2) Pathological or compulsive gamblers (Ashley \& Bohlke, 2012). Pathological gambling has been defined in 1800's in medical literature (Harvard Mental Health Letter, 2010). It was officially recognized in 1980 with the publication of the DSM-III and was classified as an impulse control disorder (American Psychiatric Association, 1980). According to DSM-IVTR to be diagnosed with pathological gambling, an individual must meet at least five of 10 criteria such as a preoccupation with gambling; needs to gamble with increasing amount of money; repeated unsuccessfull efforts to stop gambling; restless or irritable when attempting to cut down; gambles as a way of escaping from problems; "chasing" one's losses; lying to loved ones about gambling; committing "illegal acts, such as forgery, fraud, theft or embezzlement to finance gambling"; lost a significant relationship, job, or educational or career opportunity because of gambling and relies on others to provide money to relieve a desperate financial situation (American Psychiatric Association, 1994). In DSM-V, PG has renamed "gambling disorder" and moved to the category for alcohol and drug use disorders. The threshold for a diagnosis of gambling disorder will be lowered from five to four symptoms by eliminating the "illegal acts" criterion because it does not appear to be a decisive symptom for most people with gambling problems (American Psychiatric Association, 2010).

In last three decade hundreds of survey heve shown that pathological gambling prevalance has global prevalance of aproximately $\% 1$ (Wiebe \& Volberg, 2007). The minimum standardized prevalence rates of problem gambling tend to occur in Europe, with intermediate rates in North America and Australia, and the most elevated rates in Asia (Williams et. al., 2012). The rates of pathologic gambling in Hong Kong, Singapore and Macau, with high prevalence rates are around 2\% (Wong \& So 2003; Ministry of Community Development, Youth\& Sport, 2005; Fong \& Ozorio 2005). In 2007, the rate of pathological gambling was found to be $2.2 \%$ (Çakıc1, 2012). In some special populations, rates of pathological gambling are much higher than these rates. In adolescents, indigenious minority groups, among refugee and migrant populations, there is a higher rate of gambling in the same population.(Derevensky \& Gupta, 2004; Abbott \& Volberg, 1996).

Over the past decade, the nature of gambling in Northern Cyprus has been changing, due largely to the introduction of the Casinos, but also to the increasing availability of other forms of gambling such as spread-betting and gambling on the Internet. While there is growing interest in the social impact of these new forms of gambling on the Northern Cypriot population, up till now there has been little reliable information available about people's gambling behaviour. It has been shown that gambling is becoming more widespread in North Cyprus and that pathological gambling addiction is increasing. In 2007 (Çakıc1, 2012), it was found that the gambling addiction increased from $2.2 \%$ to $3.5 \%$, the gambling problem and addiction increased from $11.9 \%$ to $12.7 \%$ and the gambling game increased from $55 \%$ to $79.8 \%$. Prevalence rates similar to those identified in North Cyprus have only been found among three specific ethnic groups. These include the Puerto Rico (Volberg \& Vales, 1998), Maori in New Zealand (Abbott \& Volberg, 1996) and Native Americans in North Dakota (Volberg\& Silver, 1993). Volberg \& Vales (1998), has shown the common charactersitics of history of colonization and accompanying policies of economic exploitation and they remain relatively disadvantaged in socio-economic terms, low levels of formal education and high non-employed population. There are 82 British colonies in North Cyprus in the past year, due to the survival of a country recognized as a country dependent position located under the influence of economic embargoes and Turkey have common characteristics with this group. 
Table 1. Comparison prevalence rates for some jurisdictions and Northern Cyprus.

\begin{tabular}{|c|c|c|c|c|}
\hline $\begin{array}{l}\text { Classification of Jurisdictions* (used } \\
\text { Instrument) }\end{array}$ & $\begin{array}{c}\text { Problem } \\
\text { Prevalences } \\
\%\end{array}$ & $\begin{array}{c}\text { Probable } \\
\text { Pathological } \\
\%\end{array}$ & $\begin{array}{c}\text { Combined } \\
\%\end{array}$ & Sources \\
\hline \multicolumn{5}{|l|}{ Lower } \\
\hline Netherlands (SOGS-L) & 1.5 & 1.0 & 2.5 & De Bruin (2006) \\
\hline Great Britain (SOGS & 1.3 & 0.8 & 2.1 & Sproston et.al. (2000) \\
\hline Denmark (SOGS-L) & 1.2 & 0.5 & 1.7 & Bonke \& Borregaard (2006) \\
\hline Germany (DSM-IV-PY) & 0.64 & 0.56 & 1.2 & Meyer \& Hayer (2009) \\
\hline Norway (SOGS-L) & 0.7 & 0.3 & 1.0 & Jonsson (2006) \\
\hline Belgium (DSM-IV-PY) & 1.6 & 0.4 & 2.0 & Druine (2009) \\
\hline New Zealand & 1.9 & 1.0 & 2.9 & Abbot \& Volberg (2000) \\
\hline \multicolumn{5}{|l|}{$\underline{\text { Average }}$} \\
\hline United States (DSM-IV-PY) & 2.1 & 1.4 & 3.5 & Welte (2002) \\
\hline Switzerland (SOGS-L) & 2.2 & 1.1 & 3.3 & Bondolfi et al. (2008) \\
\hline Spain (SOGS-L) & 1.6 & 1.4 & 3.0 & Becona (2009) \\
\hline Sweden (SOGS-L) & 2.7 & 1.2 & 3.9 & Volberg et.al. (2011) \\
\hline Canada (SOGS-PY) & 1.3 & 1.3 & 2.6 & Ferris \& Wynne, 2001 \\
\hline \multicolumn{5}{|l|}{ Higher } \\
\hline Hong Kong (DSM-IV) & 4.0 & 1.8 & 5.8 & Wong \& So (2003) \\
\hline Singapore (DSM-IV) & 2.0 & 2.1 & 4.1 & Ministry of C.Y \& S. (2005) \\
\hline Macau (DSM-IV) & 2.5 & 1.8 & 4.3 & Fong \& Ozorio (2005) \\
\hline Australia (SOGS-PY) & 2.8 & 2.1 & 4.9 & Productivity Com. (2000) \\
\hline \multicolumn{5}{|l|}{ Between Higher and Extremely Higher } \\
\hline North Cyprus (2007) (SOGS-L) & 9.7 & 2.2 & 11.9 & Çakıcı (2012) \\
\hline North Cyprus (2012) (SOGS-L) & 9.2 & 3.5 & 12.7 & Çakıcı (2016) \\
\hline North Cyprus (2018) (SOGS-L) & 9.2 & 4.6 & 13.8 & Çakıcı (2019) \\
\hline \multicolumn{5}{|l|}{ Extremely Higher } \\
\hline Puerto Rico (SOGS-L) & 6.4 & 7.4 & 13.8 & Volberg \& Vales (1998) \\
\hline N.Dakota Native Americans & 7.1 & 7.1 & 14.2 & Volberg \& Silver (1993) \\
\hline New Zealand Maori (SOGS-L) & 8.7 & 5.9 & 14.6 & Abbot \& Volberg (1996) \\
\hline
\end{tabular}

*Clasification of the jurisdiction is based on Williams et al. (2012) and Volberg \& Vales (1998).

However, while there is a colony history in Portugal,

Macao tries to solve its own economic problems by turning into gambling cities with casinos. But there are also studies showing that there is a lower prevalence of problem gambling in Hong Kong which does not have a gambling city feature with similar characteristics (Fong $\&$ Ozorio 2005). These different findings suggest that the relationship between exposure and the harms of gambling is still controversial in the literature today. It was revealed that adaptation is possible to risks and losses in time(Volberg, 2011). It is observed that adaption is not developed among North Cyprus population as pathological gambling is increasing day by day. The reason for the lack of adaptation process is the increase in the number of casino and betting offices as well as the opportunities offered by these venues. The number of Betting Officers rose from 70 in 2007 to 75 in 2012 and became widespread in North Cyprus. In Northern Cyprus, Betting offices have become socially accepted places of widespread gambling of Turkish Cypriots with low incomes because they are almost the only places of entertainment in the villages. In 2007, there were 20 casinos and 315 tables and 3612 machines in these casinos. The increase in casino numbers and especially the intensity of EMGs has also been demonstrated by increasing the number of gambling problems (Storer, 2009).The facilities offered at the casinos are very attractive for locals who are not in a good economic situation and have little social facilities. Casinos today also offer free meals, alcohol and cigarettes. In the casinos, customers are offered life-packed gambling along with a package. Casinos in turn offer their customers "package" deals where gambling and prostitution are mixed (Rodríguez, 2001). The second reason is that the casinos are perceived as negative and alien and that the local people cannot adapt to the "bad" one. North Cyprus population consider casinos as the culprit behind various social, cultural, aesthetic, and environmental problems, felt and perceived the casino industry as an alien economic agent planted in their communities, which simply ran over their interests and also aware that the overwhelming majority of investments in casinos are foreign owned, which then employ foreign labor (Alipour \& Vughaingmeh, 2010). The third reason is that the casinos are forbidden to NC citizens, unlike the betting officers. It is not expected to 
create an adaptation to the forbidden one. Forbidden nature of the activities like gambling, drug, alcohol and cigarette make people specially adolescents more prone to engage in them (Netemeyer, 1998).It is seen that the ban does not prevent the increase in gambling if it is not effective. Moreover, since Northern Cyprus is a collectivist and traditional society in terms of small and family relations (Zorba 2012), gamblers undergo stigmatization. Stigmatization has been reported to be particularly important in small populations, but it has been reported that the prevalence of gambling addiction remains high due to the lack of treatment of the gambling addicts (Tse, 2003).The fourth reason is that in North Cyprus, there are currently no prevention programs to address the problems of gambling and the lack of effective treatment services for people suffering from problems.In addition to all of the reasons, the fifth factor, perhaps the basis for the high prevalence of high gambling problem prevalence, is the traditional gambling culture characteristics in North Cyprus. Although the gambling sin is illegal in Islamic culture, various forms of gambling have always been common in Turkish Cypriots life since the British rule of Cyprus. Scott (2013) has explained in antropologic article thatexisting local gambling culture and rapidly growing global casino industry mediate each other in Cyprus.

In litterature about pathological and problematic gambling, being younger than 29 years old (Volberg, 2011), male (Fong \& Orizio, 2005), un-married (Becona, 2009), unemployed (Feigelma, 1995), immigrant (Çakıcı, 2019), low education level (Dickerson, 1998) are found as risk factors. However, contrary to the information in the literature as risk factors of the host culture those immigrants who are seen higher rates of problematic gambling according to the Turkey-born immigrants born in Cyprus. Indigenous Turkish Cypriots, due to bicommunal conflicts, starting from the 1950s, they had immigrated to countries like UK, Australia, Canada. After the 1974 war since Turkish immigrants came to Cyprus, North Cyprus has fallen into minority status (Bryant \& Yakinthou, 2012). Because of the restrain relation between Turkish Cyprsiot and Turkish immigrants from Turkey, Turkish Cypriot express feelings that they have beenculturally and physically annihilated (Navaro-Yashin, 2006). Experiences of loss of culture, change in social norms, breakdown of families and loss of social or economic status are often the reasons why some people move across from being a social and recreational gambler to developing problems with gambling (Dyall, 2002). Turkish Cypriots have a minority character in the aculturation process despite the fact that they are the host culture, and that this social change may be related to increased gambling.

\section{Conclusion}

Like North Cyprus, the areas which have rapid expansion of gambling we need to learn the impact of gambling on vulnerable, at-risk and special populations. These studies will be important for understanding special groups that may be risky in the future and minimizing the losses of gambling. Special groups with high gambling prevalance have similar features and each society has its own characteristics. Problem gambling among North Cyprus people has to be seen as more than an individual problem and needs to be seen in its social context. In this article, it has become necessary to consider sociocultural characteristics while struggling with problem gambling in North Cyprus. It is clear that there is a need for further studies to understand the social impact of gambling in North Cyprus in more detail. Prevention strategies and programs will be developed in order to ensure the awareness of the society. Public campaigns need to be implemented which promote services among the NC population in order that NC gamblers are encouraged to seek help at an earlier stage. A comprehensive public health strategy must be developed with key stakeholders as a fundamental part of a strategy to reduce gamblingrelated harm in North Cyprus. Collaborative efforts between researchers, treatment providers, prevention specialists, and legislators will ultimately lead to more effective public health intervention and social policies.

\section{References}

Abbott, M. W.,\&Volberg, R. A. (1996). The New Zealand National Survey of Problem and Pathological Gambling. Journal of Gambling Studies, 12 (2), 143-160.

Abbott, M. W.,\& Volberg, R. A. (2000). Taking the pulse on gambling and problem gambling in New Zealand: phase one of the 1999 national prevalence survey. Wellington, NZ: Department of Internal Affairs.

Alipour, H.,\&Vughaingmeh, E. M. (2010). Casino Gambling Tourism-A View From Community: The Case of North Cyprus (TRNC). Journal of Rural and Community Development, 5(3), 175-202.

American Psychiatric Association, (1980). Diagnostic and statistical manual of mental disorders, 3rd edn. Washington, DC: American Psychiatric Association.

American Psychiatric Association, (1994). Diagnostic and statistical manual of mental disorders, 4th edn. Washington, DC: American Psychiatric Association.

American Psychiatric Association, (2010). Diagnostic and statistical manual of mental disorders, 5th edn. Washington, DC: American Psychiatric Association.
Ashley, L. L.,\& Boehlke, K. K. (2012). Pathological gambling: a general overview. J Psychoactive Drugs,44(1), 27-37.

Becona, E. (2009). Spain. In G. Meyer, T. Hayer, \& M. Griffiths (Eds.), Problem Gambling in Europe: Challenges, Preventions and Interventions.(pp. 137-151). New York: Springer.

Bondolfi, G., Osiek, C., \& Ferrero, F. (2008). Prevalence estimates of pathological gambling in Switzerland. Acta Psychiatrica Scandinavica,117, 236-239.

Bonke, J.,\& Borregaard, K. (2009). The prevalence of problematic gambling behavior: A Scandinavian comparison. Scandinavian journal of public health,37, 654-60.

Bryant, R.,\& Yakinthou, C. (2012). Cypriot Perception of Turkey. İstanbul, Turkey: Turkish Economic and Social Studies Foundation (Pub.).

Campbell, CS.,\& Smith, G.J. (2003). Gambing in Canada- From vice to disease to responsibility: A negotiated history. $C B M H$, 20(1), 121-49.

Çakıcı, M. (2012). The prevalence and risk factors of gambling behavior in Turkish Republic of Northern Cyprus. Anadolu Psikiyatri Dergisi, 13(4), 243-249. 
Cakıcı, M., Cakıcı, E., \&Karaaziz, M. (2015). Lifetime of Prevalance and Risk Factors of Problem and Pathologic Gambling in North Cyprus. Journal of Gambling Studies,31(1), DOI 10.1007/s10899-015-9530-5.

Çakıcı, M., Çakıcı, E., Karaaziz, M., Babayiğit, A. (2019). The relationship between gambling prevalence, risk factors and cultural attitudes in NC: 2007- 2014. Anatolian Journal of Psychiatry, doi: 10.5455/apd.7939

De Bruin, D.E., Meijerman, C.J.M., Leenders, F.R.J., \& Braam, R.V. (2006). Verslingerd aan meer dan één spel: Een onderzoek naar de aard en omvang van kansspelproblematiek in nederland [Wired to more than one game. A study on the nature and extent of problem gambling in the Netherlands]. Den Haag: Research and Documentation Centre of the Ministry of Justice, commissioned by the Ministry of Justice

Derevensky, J.,\& Gupta, R. (2004). Gambling problems in youth: theoretical and applied perspectives. New York: Kluwer Academic/Plenum Publishers.

Dickerson, M. (1998). Gambling. A Dependence Without a Drug. International Review of Psychiatry, I (March), 157-72.

Druine (2009). Belgium. In G. Meyer, T. Hayer, \& M. Griffiths (Eds.), Problem Gambling in Europe: Challenges, Prevention, and Interventions. New York: Springer.

Duvarc1, İ.,\& Varan, A. (2000). Descriptive Features of Turkish Pathological Gamblers. Scandinavian Journal of Psychology, 41, 253-260.

Dyall, L. (2002). Kanohi ki te kanohi: Face to face. A Maori face to gambling. New Ethicals Journal: New Zealand's Journal of Patient Management, 5 (1), 11-16.

Feigelman, W., Kleinman, P.H., Lesieur, H.R., Millman, R.B.,\& Lesser, M.L. (1995). Pathological gambling among methadone patients. Drug and Alcohol Depend, 39, 75-81.

Ferris, J.,\& Wynne, H. (2001). The Canadian Problem Gambling Index: User Manual. January 28, 2001. Submitted to the Canadian Centre on Substance Abuse.

Fong, D. K. C.,\& Orozio, B. (2005). Gambling participation and prevalence estimates for pathological gambling in a far east gambling city: Macau. UNLV Gaming Research \& Review Journal, 9(2), 15-28.

Harvard Mental Health Letter (2010). Pathological gambling. Harvard Mental Health Letter, 27(2), 1-3.

Jonsson, J. (2006). An overview of prevalence surveys of problem and pathological gambling in the Nordic countries. Journal of Gambling Issues, 18.

Lesieur, H.R.,\& Rosenthal, R.J. (1991). Pathological gambling: a review ofthe literature (prepared for the American Psychiatric Association Task Force on DSM-IV Committee on Disorders of Impulse Control Not Elsewhere Classified). Journal Gamble of Study, 7, 5-39.

Ministry of Community Development, Youth and Sports (2005). Ministry of Community Development, Youth and Sports Survey. Singapore: Author

Navaro-Yashin, Y. (2006). De-ethnicizing the Ethnography of Cyprus: Political and Social Conflict between Turkish Cypriots and Settlers from Turkey. Divided Cyprus: Modernity, History, and an Island in Conflict, edited by Papadakis, Y., Peristianis, N., \& Welz, G., Bloomington, USA: Indiana University Press (Pub.), 84-99.

Netemeyer, R. G., Burton, S., Cole, L.K., Williamson, D. A., Zucker, N., Bertman, L., \& Diefenbach, G. (1998). Characteristics and beliefs associated with probable pathological gambling: a pilot study with implications for the national gambling impact and policy commission. J Public Policy Mark,17(2), 147-160.
Productivity Commission, (2000). Australia's gambling industries, report no. 10. Chapter 6 . What is problem gambling? \& Appendix F. National Gambling Survey. Canberra: Austrilian Information.

Rodríguez, L., Guven-Lisaniler, F., \& Ugural, S. (2001, November). Sex work and state regulations in North Cyprus. In International Political Economy Association annual conference, Florence, November.

Scott, J. E.,\& Asikoglu, S. (2001). "Gambling with Paradise? Casino Tourism Development Northern Cyprus". Tourism Recreation Research, 26(3), 51-61.

Scott, J. E. (2001). "Everything's Bubbling, But We Don't Know What the Ingredients Are"-Casino Politics and Policy in the Periphery. Journal of Gambling Issues, 4.

Scott, J. E. (2003). Coffee Shop Meets Casino: Cultural Responses to Casino Tourism in Northern Cyprus. Journal of Sustainable Tourism, 11(2/3), 266-279.

Scott, J. E. (2013). Playing Properly: Casinos, Blackjack and Cultural Intimacy in Cyprus. In Qualitative Research in Gambling: Exploring the production and consumption of risk, edited by Rebecca Cassidy, Andrea Pisac and Claire Loussouarn. New York: Routledge (Pub.), 125-139.

Shaffer, H.J.,\& Hall, M. M. (1996). Estimating the prevalence of adolescent gambling disorders: A quantitative synthesis and guide toward standard gambling nomenclature. Journal of Gamble Studies, 12(2),193-214.

Sproston, K., Erens, B.,\& Orford, J. (2000). Gambling behaviour in Britain: results from the British gambling prevalence survey. London: National Centre for Social Research.

Storer, J., Abbott, M.,\& Stubbs, J. (2009). Access or adaptation? A meta-analysis of surveys of problem gambling prevalence in Australia and New Zealand with respect to concentration of electronic gaming machines. International Gambling Studies, 9(3), 225-244.

Tse, S. (2003). From blaming to changing: An Asian perspective in Aotearoa. Paper presented at the 3 rd International Conference on Gambling ("Gambling through a public health lens: Health promotion, harm minimisation and treatment"), Auckland, New Zealand.

Volberg, R.A.,\& Silver, E. (1993). Gambling and Problem Gambling in North Dakota. Report to the North Dakota Department of Human Services, Division of Mental Health. Albany, NY: Gemini Research.

Volberg, R.A.,\& Vales, P.A. (1998). Gambling and Problem Gambling in Puerto Rico [Juegos de azar y el problema de juego en Puerto Rico]. Report to the Puerto Rico Treasury Department.

Volberg, R.A. (2000). Quick draw players in New York State: a comparison of data from 1996 and 1999. Albany NY: New York State Office of Mental Health.

Volberg, R.A., Abbott, M.W., Ronnberg, S.,\& Munck, I.M.E. (2011). Prevalence and risks of pathological gambling in Sweden. Acta Psychiatrica Scandinavica, 104, 250-256.

Welte, J.W., Barnes, G. M., Wieczorek, W.F., Tidwell, M. C., \& Parker, J. (2002). Gambling participation in the U.S. - results from a national survey. Journal of Gambling Studies, 18(4), 313337.

Wiebe, J.,\& Volberg, R. A. (2007). Problem Gambling Prevalence Research: A Critical Overwiev. A report to the Canada Gaming Association. http://www.toronto.ca/legdocs/mmis/2013/hl/con.

Williams, R.J., Volberg, R.A.,\& Stevens, R.M.G. (2012). The Population Prevalence of Problem Gambling: Methodological Influences, Standardized Rates, Jurisdictional Differences, and Worldwide Trends. Report prepared for the Ontario Problem 
Gambling Research Centre and the Ontario Ministry of Health and Long Term Care.

Wong, L. K.,\& So, M. T. (2003). Prevalence estimates of problem and pathological gambling in Hong Kong. American Journal of Psychiatry, 160(7), 1353-1354.
Zorba, A.B. (2012). Northern Cypriot Culture and its impact on attitudes towards mentally ill; $A$ qualitative study.(Unpuplished thesis). Centre for Psychiatry Old Anatomy Building, Wolfson Institute of Preventative Medicine, Barts and the London Queen Mary's School of Medicine and Dentistry, Charterhouse Square, London, EC1M 6BQ. 